\title{
Litterfall production in forests located at the Pre-delta area of the Paraná River (Argentina)
}

\author{
Pablo G. AcEÑolazA ${ }^{1,2 *}$, Lisandra P. ZAMBOnI ${ }^{2}$, Estela E. RodrigueZ ${ }^{1,2}$, Juan. F. GALlARdo ${ }^{3}$ \\ ${ }^{1}$ CICyTTP-CONICET, Materi y España, Diamante 3105, Entre Ríos, R. Argentina \\ ${ }^{2}$ CEREGeo-FCyT. Universidad Autónoma de Entre Ríos. Ruta 11, km 10,5, Oro Verde, Entre Ríos, R. Argentina \\ ${ }^{3}$ C.S.I.C., IRNASa, Apartado 257, 37071 Salamanca, España
}

(Received 17 February 2009; accepted 9 September 2009)

Keywords:

litterfall production /

forest litter /

floodplain /

flood pulse /

Paraná river
Mots-clés :

production de litière forestière /

litières forestières /

plaine alluviale /

impulsions d'inondation /

rivière Paraná

\begin{abstract}
- The objectives of this study were to measure litterfall production of the four floodplain forest types and to analyze the relationship between litterfall (forest type, dominant species, and organic fractions) and flood pulses.

- Litterfall production was measured in two mono-specific stands of Salix humboldtiana or Tessaria integrifolia, respectively, and two mixed forests dominated by A. inundata or Nectandra angustifolia, during 1998 and the 2000-2002 periods.

- Mono-specific stands presented similar productivities $\left(6.8\right.$ and $6.5 \mathrm{Mg}$ dry matter $\mathrm{ha}^{-1} \mathrm{y}^{-1}$, respectively), but differed significantly from the two other. The highest litterfall production was obtained during the large flood that occurred during 1998, decreasing later throughout the study period. Leaves were the dominant fraction of litterfall, followed by branches, flowers, and fruits.

- Only S. humboldtiana, T. integrifolia and A. inundata forests showed distinct patterns of litterfall production, depending on the flooding pulse. $N$. angustifolia did not show a distinctive litterfall pattern.

- The forests studied here presented patterns of litter production associated with the flood pulse according to its location along a topographic gradient, that controls the litter productivity of these
\end{abstract} forests.

Résumé - Production de litières par des forêts situées dans le pré-delta du fleuve Paraná (Argentine).

- Cette étude avait pour but de mesurer la production de litière dans quatre forêts alluviales et d'analyser les relations entre les litières (selon le type de forêt, l'espèce dominante, et des fractions organiques) et les crues du fleuve Paraná (Argentine).

- La production de litière a été mesurée dans deux forêts monospécifiques de Salix humboldtiana ou de Tessaria integrifolia, et dans deux forêts mixtes où l'espèce prédominante était soit Albizia inundata soit Nectandra angustifolia. Cette étude a été menée en 1998 puis de 2000 à 2002.

- Les forêts monospécifiques présentent des productions de litières similaires (6.8 et $6.5 \mathrm{Mg}$ matière sèche $\mathrm{ha}^{-1} \mathrm{ans}^{-1}$ respectivement) et étaient significativement différentes des deux forêts mixtes. La plus forte production de litière a été obtenue au cours de la grande crue de 1998, puis a diminué progressivement au cours du temps. Les feuilles représentaient la principale fraction des litières, tandis que les branches, les fleurs et les fruits constituent des fractions mineures.

- Les forêts dominées par $S$. humboldtiana, T. integrifolia et $A$. inundata ont vu leur production de litière évoluer en fonction des crues du fleuve Parana. Ce type de relation entre crue et production de litière n'a pas été détecté dans le cas des forêts de $N$. angustifolia.

- Il existe ainsi une relation entre la production de litière et la hauteur des crues, elle-même conditionnée par un gradient topographique, qui détermine donc la production de litière de ces forêts.

*Corresponding author: acenolaza@gmail.com 


\section{INTRODUCTION}

Landscape structure, dynamics, and succession depend greatly on interactions of soil, vegetation, and regional environmental factors. Soil organic matter comes mainly from decomposition of plant remains, or litterfall, that reach the soil after abscission: leaves, branches, flowers, fruits, and other plant structures, (Grigg and Mulligan, 1999; Hasee, 1999). Release of nutrients from the forest litter is determined by biochemical characteristics of species, annual variability of litterfall, physical-chemical properties of litters, and environmental conditions. The size and the distribution of these $\mathrm{C}$ pools are heterogeneous and vary depending on the type of forest in relation to climate, soil management, frequency of disturbance, and level of human-induced degradation (Eglin et al., 2008). In this context, the analysis of litterfall contribution to soil constitutes a suitable way of estimating forest productivity (Aceñolaza et al., 2006; Bray and Gorham, 1964; Carnevale and Lewis, 2001; Haase, 1999; Monedero and González, 1995; Santa Regina et al., 1991; Zamboni and Aceñolaza, 2004).

In alluvial floodplains, ecosystem processes like litterfall are closely associated to hydrologic characteristics (Brinson et al., 1980; Junk et al., 1989) or to the hydro-sedimentologic pulse (Neiff, 1990).Thus, in alluvial forests subject to seasonal floods, the input and output of water strongly affect their dynamics with regard to biogeochemical cycles. In general, these ecosystems exhibit high productivity and fast decomposition rate of organic layer ( $O$ horizon) in comparison to other aquatic or non-flooded ecosystems (Haase, 1999; Junk et al., 1989).

The existence of peaks in ecological processes in forests with recurrent floods (with species tolerant to temporal hydromorphy) results in a pulse-dependent pattern of activity. Leaffall is often high in the flooding phase, although there may be a less intense secondary defoliation throughout the year. Fructification, germination, and seed growth are also usually positively related to the flooding phase (Godoy et al., 1999).

Although some information on productivity of SouthAmerican alluvial forests is available, there is a lack of information as regards seasonal forests of this sub-continent (Haase, 1999; Proctor, 1983, 1984).

With reference to the alluvial plain of the Paraná River (Argentina), information remains scarce and restricted to the works of Neiff and Poi de Neiff (1990) and those of Zamboni and Aceñolaza (2004), and Aceñolaza et al. (2006).

According to Zamboni and Aceñolaza (2004), forest systems of the study area (Pre-delta) can be defined by species composition, structural features, phenology, flowering, fructification, seed dispersal, biomass, and litterfall production, among others. They distinguished following systems: (a) "simple" forests, generally mono-specific stands of S. humboldtiana Willd. (1806) or T. integrifolia Ruiz and Pav. (1798) with scarcely developed herb and shrub strata, located in marginal sand banks of the river bed (levee deposits subject, to high energy seasonal floods) and acting as colonizer species; and (b) "mixed" forests dominated by A. inundata (Mart.) Barneby and J.W. Grimes (1996) or Nectandra angustifolia (Schrad.) Nees and Mart. (1833), with higher species richness, and with a developed strata of liane located in internal levee deposits, with a rather indirect influence of hydrological variations.

The production of litterfall from the dominant species may be an important variable for examining the phenology of these forests types. In mono-specific forests, the pattern of litterfall production from dominant species may describe the overall pattern of forest production, while this may not occur in mixed forests (Zamboni and Aceñolaza, 2004). This is a simple way to determine the forest phenology based on the litterfall pattern of the dominant species. In this way the analysis is simplified because it is considered only a single variable that represents the pattern of litter-fall of the forest.

Soil moisture controls the amount of $\mathrm{C}$ assimilated by vegetation photosynthesis and the $\mathrm{C}$ decomposed and incorporate to soils; therefore, soil moisture is a key controller of vegetation, an then of litterfall production and soil C stocks (Eglin et al., 2008). In conditions of high soil water content (flooding phase) oxygen supply to micro-organism activities is restricted, and then decomposition rates of organic residues decrease and more organic matter therefore accumulates in the system (usually there is either standing litter or soil organic-C accumulation).

Litterfall cannot be simply linked to water-logging intensity, as other factors like species composition, species physiological responses, winds, and forest management practices gain in importance (Eglin et al., 2008). In this context, it can be hypothesized that tree species could be influenced by the floodplain hydrology; as a consequence of this, the temporal variability of water logging should affect the variability of litterfall.

In this context, the objectives of present study were double: (a) to measure and compare litterfall production rates in Pre-delta forests of the Paraná River between forests for the period studied (1998 and 2000-2002); and (b) to analyze the relationship between litterfall production patterns and the hydrological regime.

\section{MATERIALS AND METHODS}

\subsection{Study area}

The study was carried out in Pre-delta National Park (PNPD), located $5 \mathrm{~km}$ from the village of Diamante $\left(32^{\circ} 03^{\prime} 43^{\prime \prime} \mathrm{S}\right.$ and $60^{\circ} 38^{\prime} 39^{\prime \prime} \mathrm{W}$; Province of Entre-Ríos, Argentina). The PNPD (Fig. 1) was declared a protected area in 1992 under the jurisdiction of National Parks Administration (APN), which allowed the conservation of landscapes and protection from livestock overgrazing (one of the main factors of ecological degradation in the region).

The Park covers an area of $24.6 \mathrm{~km}^{2}$, mainly represented by water bodies, small islands, and, some cliffs at the river banks. Climate, according Rojas and Saluso (1987), is wet (mean annual rainfall about $1126 \mathrm{~mm} \mathrm{y}^{-1}$ ) and from temperate to warm (mean annual temperature around $19{ }^{\circ} \mathrm{C}$ ), with rains concentrated in spring (October to December); mean: $348 \mathrm{~mm}$ ) and summer (January to March; mean: $425 \mathrm{~mm}$ ). It should be noted that, in recent years, rainfall has occurred more frequently in autumn, which locally increases the height of the river level $\left(h_{\mathrm{wl}}\right)$. 


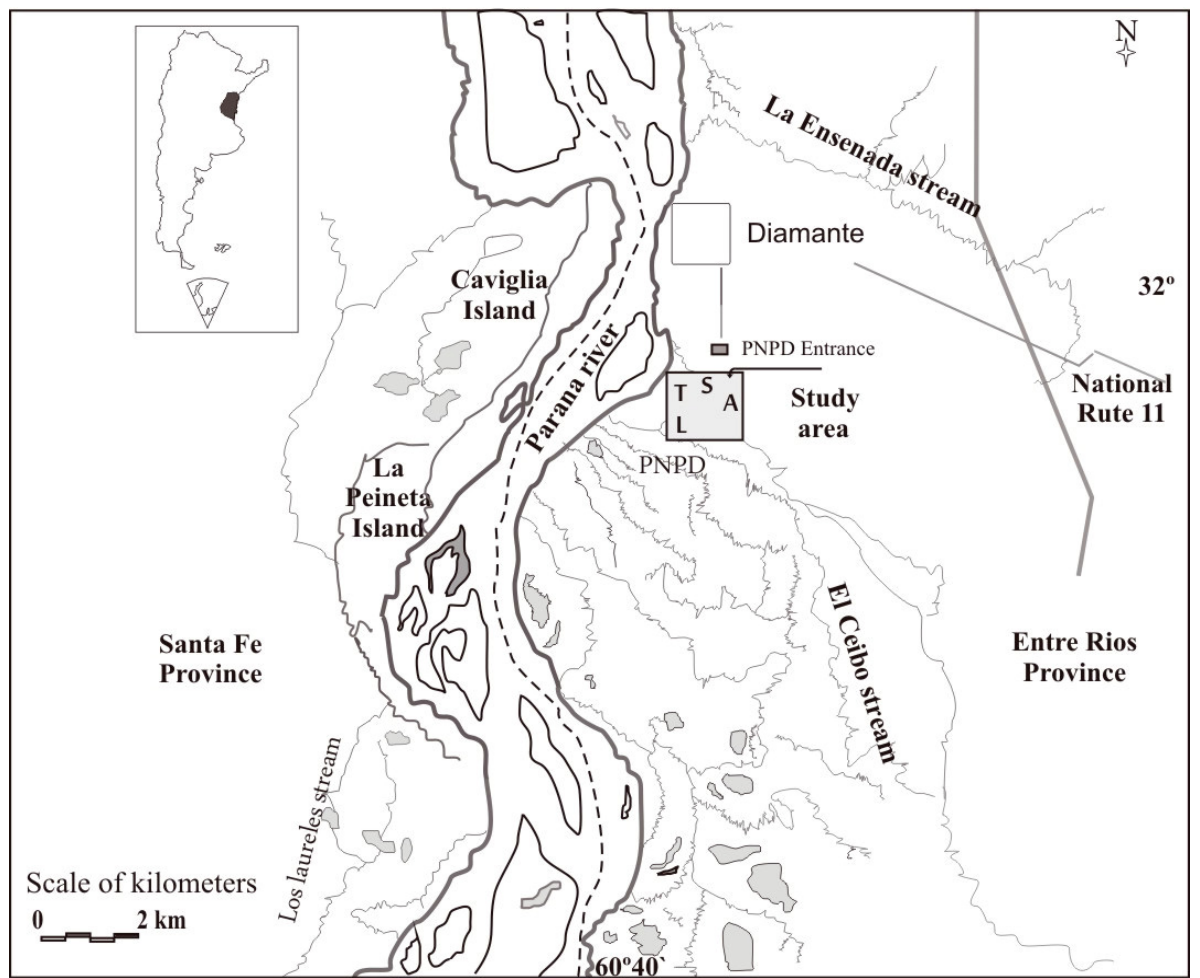

Figure 1. Geographic location of the study area (Delta of the Paraná River, Province of Entre-Ríos, North-Western Argentina). Localization of forest sites: T: Albizia inundata forest; S: Salix humboldtiana forest; A: Tessaria integrifolia forest; and L: Nectandra angustifolia forest.

The hydrologic regime of the Paraná system shows an annual (unimodal) flood pulse, occurring generally during autumn (from April to June, i.e., when rainfalls are declining), followed by a period of declining of the groundwater level during summer (from January to March), when soil-water deficit are recorded (Neiff, 1990; Zamboni and Aceñolaza, 2004) because evapo-transpiration exceeds rainfalls.

Island morphology (Aceñolaza et al., 2005, 2008) is characterized by higher external borders (marginal levee deposits), where monospecific forests of $S$. humboldtiana and T. integrifolia are found; internal thin levee deposits (with T. integrifolia forests) and, among these, other older levee deposits with $N$. angustifolia forests (Marchetti and Aceñolaza, 2005).

With regard to the phenological characteristics of the species studied, S. humboldtiana and T. integrifolia are semi-deciduous colonizers (Aceñolaza et al., 2005; Jozami and Muñoz, 1984), forming mono-specific forests with approximately 820 trees ha $^{-1}$. A. inundata is a deciduous species (Jozami and Muñoz, 1984), having a tree density of about 1060 trees ha ${ }^{-1}$. N. angustifolia is the only evergreen species (Jozami and Muñoz, 1984), with lower tree density and lineal structure (100 trees $\left.\mathrm{ha}^{-1}\right)$. In spite that $A$. inundata is a leguminous, there is not evidence that any of these four species has capacity for $\mathrm{N}$ fixing.

\subsection{Methodology}

Following the methodology of Gauch (1982), four forest types representative of the alluvial plain of the Paraná River in the area were selected. Two "simple" forests, of S. humboldtiana and T. integrifolia, respectively and two "mixed" forests, one dominated by
A. inundata and the other by $N$. angustifolia, were analyzed for $5 \mathrm{y}$ (1998 to 2002). Unfortunately, part of data corresponding to 1999 was incomplete due to vandalisms and is not included. Similarly, it was impossible to get data from the $N$. angustifolia site from the last two years (2001 and 2002).

For each forest type, the analyzed characteristics included the composition of litterfall, monthly and mean annual litterfall production, and inter-annual variation.

The structural data gathered from previous studies of these forests provided by the authors (Aceñolaza et al., 2006; Zamboni and Aceñolaza, 2004), are also used in this study.

In homogeneous areas of the four forest types traps were placed under the tree canopy, at a distance of 10-15 m between them. We assumed that collection of the traps was independent.

Litter production was studied by the method of estimating plant contribution to soil (Aceñolaza et al., 2006). Litterfall was collected monthly in traps of $0.25 \mathrm{~m}^{2}$; the number of traps for forest in monospecific and $A$. inundata forests was four, and the number of recollection was 48 in a year (4 per month during 12 months). In the N. angustifolia forest, only three traps were considered due to accidental loss of the 4th sampling, and the number of recollection for one year was 36 ( 3 per month for 12 months).

The material that was collected was dried at $70{ }^{\circ} \mathrm{C}$, until constant weight was reached; then classified and weighed in four categories: (a) "leaf production"; (b) "branches"; (c) "flowers+fruits" (here it is impossible to differentiate those from dominant species from those of other species due to their small size); and (d) "others", including plant material of the remaining species (either trees, shrubs or herbs) and unrecognizable fragments. 


\section{Forest Litterfall production (1998 and 2000-2002)}

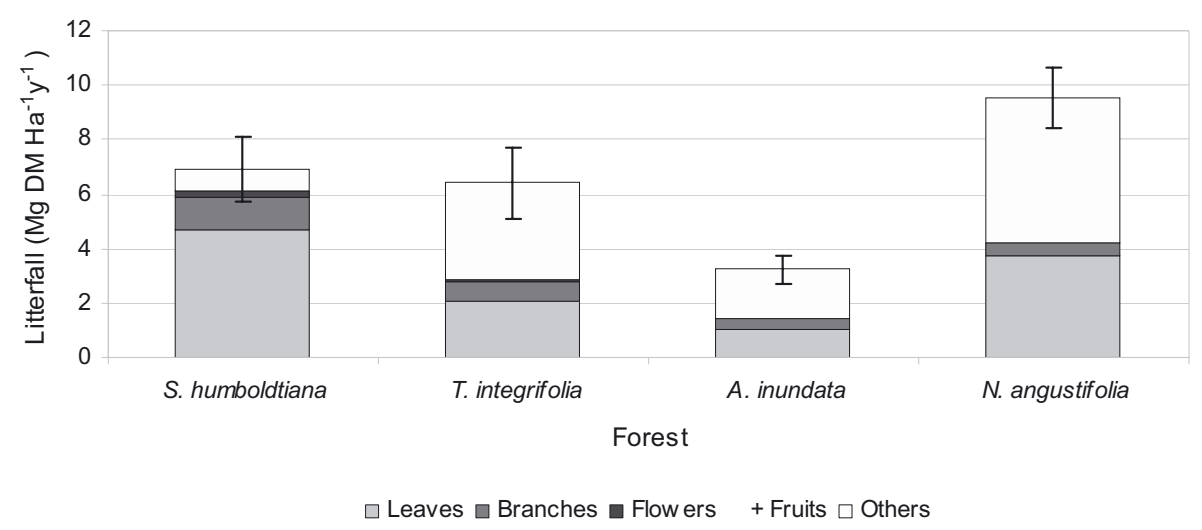

Figure 2. Forest litterfall production (mean $\mathrm{Mg} \mathrm{DM} \mathrm{ha}^{-1} \mathrm{y}^{-1}$ and its standard error) in forests of: T. integrifolia; S. humboldtiana; A. inundata; and N. angustifolia, located in the P.N.P.D. (period: 1998-2002). The total and fraction (leaf, branches, and flowers+fruits) production is indicated for the study period.

Results are given in Megagrams (Mg) of dry matter (DM) by ha ${ }^{-1}$ and $\mathrm{y}^{-1}$.

Heights of the river level $\left(h_{\mathrm{wl}}\right)$ corresponded to those recorded by the "Prefectura Naval Argentina" at the Diamante city. They are given by each complete month.

The following four seasons were identified, according to the Austral Hemisphere: winter (July to September), spring (October to December), summer (January to March), and autumn (April to June).

\subsection{Statistical analysis}

Average monthly production of litterfall was obtained for each month of the period of study, from January 1998 to December 2002. Each year was considered from January to December.

Monthly production was estimated separately for leaf, branches, fruits and flowers, and other structures of different species. The annual average of litterfall was obtained summing the means of monthly production. The total average for the period of study was obtained from the values of all the years studied.

Normality tests (modified Shapiro-Willks; SW) were applied to analyze the distribution of litterfall production of the four forest plots and river level height. Since data did not show a normal distribution, despite of data transformations, the Kruskal-Wallis test (KW, a non-parametric test similar to the ANOVA) was used to perform a non-parametric analysis of variance ( $H$ statistic), with litter-fall production as the dependent variable and forest units, fractions, and sampling dates as grouping factors.

Spearman correlation coefficient (non parametric measure of association based on ranges, used for not-normally distributed variables) was used to analyze the degree of association between the variables of litterfall production and height of river levels.

These sampling, treatments, and data analyses techniques (Infostat, 2002) have been widely used elsewhere (Brinson et al., 1980; Carnevale and Lewis, 2001; Clarke and Allaway, 1996; Grigg and Mulligan, 1999; Haase, 1999; Neiff and Poi de Neiff 1990; Raimundo et al., 2008; Santa Regina et al., 1991; Williams-Linera and Tolomé, 1996; Zamboni and Aceñolaza, 2004).

\section{RESULTS}

\subsection{Total mean litterfall production}

\subsubsection{Forest litterfall production (Fig. 2)}

Mean production (years 1998-2002) of litterfall in the forests studied herein varied from $3.3 \mathrm{Mg} \mathrm{ha}^{-1} \mathrm{y}^{-1}$ in the $A$. inundata to $9.6 \mathrm{Mg} \mathrm{ha}^{-1} \mathrm{y}^{-1}$ in $N$. angustifolia; i.e., mixed-forest productions are in the extremes of the measured litterfall productions. Therefore, mixed forests presented significant differences among them, and also with mono-specific forests. No significant difference was found between the litterfall production of mono-specific forests across all years $(H=243$, $p<0.001 * * *)$.

\subsubsection{Composition by fractions (Tab. I; Fig. 2)}

The litterfall recovered in the $S$. humboldtiana forest is composed by leaves $(69 \%)$, branches (17\%), flowers and fruits $(3 \%)$ and other structures $(11 \%)$. T. integrifolia and $A$. inundata forests presented litterfalls composed by leaves $(32 \%)$, branches $(12 \%)$, flowers and fruits $(2 \%)$ and other structures (54\%); and N. angustifolia litterfall is composed by leaves $(39 \%)$, branches $(5 \%)$, flowers and fruits ( $<1 \%$ ), and other structures (55\%). In T. integrifolia, N. angustifolia and A. inundata forests, leaf production contributed less than $40 \%$ to total litterfall. Leaf production was significantly different among the four forest sites for the study period $(H=336, p<0.001 * * *)$.

Branches constituted 6 to $18 \%$ of litterfall for the complete studied period. The highest production for the studied period corresponded to the $S$. humboldtiana forest $\left(1.2 \mathrm{Mg} \mathrm{ha}^{-1} \mathrm{y}^{-1}\right)$, which was significantly different from the other forests $(H=$ 87.1, $p<0.001 * * *)$.

The contribution of reproductive structures to litter was scarce (less than 3\%) for the studied period. Mixed forests 
Table I. Mean monthly values of litterfall production (Mg DM ha $\left.\mathrm{M}^{-1} \mathrm{y}^{-1}\right)$ of mono-specific forests of T. integrifolia and S. humboldtiana, and mixed forests of A. inundata and N. angustifolia, located in the P.N.P.D., during each study year (1998, 2000, 2001, and 2002). Mean monthly production of each forest site (total mean) for the whole study period 1998-2002 is indicated. nd: no data available (in brackets, standard error).

\begin{tabular}{|c|c|c|c|c|c|c|c|c|}
\hline Forests & Number of samples & Years & Leaves & Branches & Flowers + fruits & Others & Total & Leaves / Branches \\
\hline \multicolumn{9}{|l|}{ Sauce } \\
\hline \multirow[t]{6}{*}{ S. humboldtiana } & 48 & 1998 & $5.58( \pm 0.15)$ & $1.40( \pm 0.10)$ & $0.25( \pm 0.01)$ & $0.97( \pm 0.05)$ & $8.17( \pm 0.16)$ & 4,0 \\
\hline & 48 & 2000 & $4.83( \pm 0.16)$ & $1.10( \pm 0.06)$ & $0.19( \pm 0.01)$ & $0.63( \pm 0.03)$ & $6.71( \pm 0.18)$ & 4,0 \\
\hline & 48 & 2001 & $5.04( \pm 0.13)$ & $1.10( \pm 0.07)$ & $0.12( \pm 0.01)$ & $0.67( \pm 0.04)$ & $6.89( \pm 0.16)$ & 4.8 \\
\hline & 48 & 2002 & $3.15( \pm 0.14)$ & $1.20( \pm 0.09)$ & $0.13( \pm 0.01)$ & $0.77( \pm 0.05)$ & $5.30( \pm 0.21)$ & 2.5 \\
\hline & 192 & Average & $4.7( \pm 1.0)$ & $1.2( \pm 0.2)$ & $0.2( \pm 0.1)$ & $0.8( \pm 0.2)$ & $6.8( \pm 1.2)$ & 3.9 \\
\hline & & $\%$ & 69 & 18 & 2.6 & 10.4 & 100 & \\
\hline \multicolumn{9}{|l|}{ Aliso } \\
\hline \multirow[t]{6}{*}{ T. integrifolia } & 48 & 1998 & $2.41( \pm 0.08)$ & $0.80( \pm 0.04)$ & $0.24( \pm 0.04)$ & $4.35( \pm 0.11)$ & $7.77( \pm 0.20)$ & 3.2 \\
\hline & 48 & 2000 & $2.03( \pm 0.06)$ & $0.80( \pm 0.06)$ & $0.11( \pm 0.01)$ & $3.68( \pm 0.08)$ & $6.64( \pm 0.16)$ & 2.5 \\
\hline & 48 & 2001 & $2.44( \pm 0.08)$ & $0.60( \pm 0.03)$ & $0.14( \pm 0.02)$ & $3.72( \pm 0.07)$ & $6.90( \pm 0.10)$ & 4.1 \\
\hline & 48 & 2002 & $1.64( \pm 0.09)$ & $0.60( \pm 0.04)$ & $0.10( \pm 0.01)$ & $2.32( \pm 0.08)$ & $4.63( \pm 0.20)$ & 2.7 \\
\hline & 192 & Average & $2.1( \pm 0.4)$ & $0.70( \pm 0.1)$ & $0.1( \pm 0.1)$ & $3.5( \pm 0.9)$ & $6.5( \pm 1.3)$ & 3,0 \\
\hline & & $\%$ & 33 & 10 & 2 & 55 & 100 & \\
\hline \multicolumn{9}{|l|}{ Timbó } \\
\hline \multirow[t]{6}{*}{ A. inundata } & 44 & 1998 & $0.87( \pm 0.07)$ & $0.60( \pm 0.06)$ & $0.04( \pm 0.01)$ & $1.5( \pm 0.08)$ & $3.02( \pm 0.10)$ & 1.2 \\
\hline & 48 & 2000 & $1.23( \pm 0.10)$ & $0.10( \pm 0.02)$ & $0.03( \pm 0.01)$ & $2.42( \pm 0.09)$ & $3.80( \pm 0.12)$ & 9.3 \\
\hline & 48 & 2001 & $1.19( \pm 0.14)$ & $0.40( \pm 0.04)$ & $0.05( \pm 0.01)$ & $1.79( \pm 0.06)$ & $3.42( \pm 0.14)$ & 3.3 \\
\hline & 47 & 2002 & $0.59( \pm 0.03)$ & $0.50( \pm 0.03)$ & $0.03( \pm 0.01)$ & $1.52( \pm 0.09)$ & $2.61( \pm 0.08)$ & 1.3 \\
\hline & 185 & Average & $1.0( \pm 0.3)$ & $0.40( \pm 0.2)$ & $0.04( \pm 0.01)$ & $1.8( \pm 0.4)$ & $3.3( \pm 0.5)$ & 2.5 \\
\hline & & $\%$ & 30 & 12.5 & 1 & 56.5 & 100 & \\
\hline \multicolumn{9}{|l|}{ Laurel } \\
\hline \multirow[t]{6}{*}{ N. angustifolia } & 36 & 1998 & $4.73( \pm 0.17)$ & $0.50( \pm 0.02)$ & $0.07( \pm 0.01)$ & $5.06( \pm 0.33)$ & $10.34( \pm 0.33)$ & 10.1 \\
\hline & 36 & 2000 & $2.65( \pm 0.18)$ & $0.60( \pm 0.05)$ & $0.01( \pm 0.00)$ & $5.51( \pm 0.14)$ & $8.81( \pm 0.24)$ & 4.3 \\
\hline & 0 & 2001 & nd & nd & nd & nd & nd & $\mathrm{Nd}$ \\
\hline & 0 & 2002 & nd & nd & nd & nd & nd & $\mathrm{Nd}$ \\
\hline & 72 & Average & $3.7( \pm 1.5)$ & $0.5( \pm 0.1)$ & $0.04( \pm 0.01)$ & $5.3( \pm 0.3)$ & $9.6( \pm 1.1)$ & 6.2 \\
\hline & & $\%$ & 39,0 & 6,0 & 0.4 & 54.6 & 100 & \\
\hline
\end{tabular}

had significantly lower values for flowers and fruits than found in the mono-specific forests. These latter forests (with 0.10 and $0.20 \mathrm{Mg} \mathrm{ha}^{-1} \mathrm{y}^{-1}$ for $T$. integrifolia and $S$. humboldtiana, respectively) also differed between them $(H=204$, $p<0.001 * * *)$.

Over $50 \%$ of the total litterfall production of T. integrifolia, $N$. angustifolia and A. inundata forests originated from other species. In T. integrifolia forest, the leaf production come from $S$. humboldtiana trees located outside of the forests (probably leaves transported by wind). Consequently, the contribution of "others" was significantly different in the four studied forest ( $H=347, p<0.001 * * *)$, with the highest value corresponding to the $N$. angustifolia forest $\left(5.3 \mathrm{Mg} \mathrm{ha}^{-1} \mathrm{y}^{-1}\right.$, assuming $55 \%$ of total litterfall production) and the lowest value to the S. humboldtiana forest $\left(0.80 \mathrm{Mg} \mathrm{ha}^{-1} \mathrm{y}^{-1}\right.$, representing $10 \%$ of the total litterfall production).

\subsection{Inter-annual variation in total litterfall production}

\subsubsection{Forest litterfall production (Fig. 3)}

The $N$. angustifolia forest was excluded from the analysis of inter-annual variation because this site was only sampled during two years. Considering the inter-annual total litterfall production of the other three forests, the contribution in 2002 was significantly lower than in the remaining years in the three considered forests (T. integrifolia: $H=12.9, p=0.005^{* * *}$; S. humboldtiana: $H=13.9, p<0.005^{* * *}$; and A. inundata: $\left.H=8.96, p<0.05^{*}\right)$.

\subsubsection{Litterfall fractions (Tab. I)}

A decline in the leaf production in the forests was also observed from 1998 to 2002, being 1998 the year with maximum leaf production, but the variation was not significant in the $A$. inundata forest. Then, differences were statistically significant only for mono-specific forests (S. humboldtiana: $H=$ 42.5, $p<0.001^{* * *} ;$ T. integrifolia: $H=18.6, p<0.0005^{* * *}$; and $A$. inundata: $H=2.8, p>0.05)$.

No significant differences in the contribution of branches were found from 1998 to 2002, except for the A. inundata, that in 2000 presented significant lower values (A. inundata: $H=31.2, p<0.001^{* * * ;}$ T. integrifolia: $H=4.44, p<0.05^{*}$; and $S$. humboldtiana: $H=0.64, p>0.05)$.

No inter-annual variation in the contribution of reproductive structures was found in T. integrifolia and A. inundata forests. 


\section{Forest anual litterfall production}

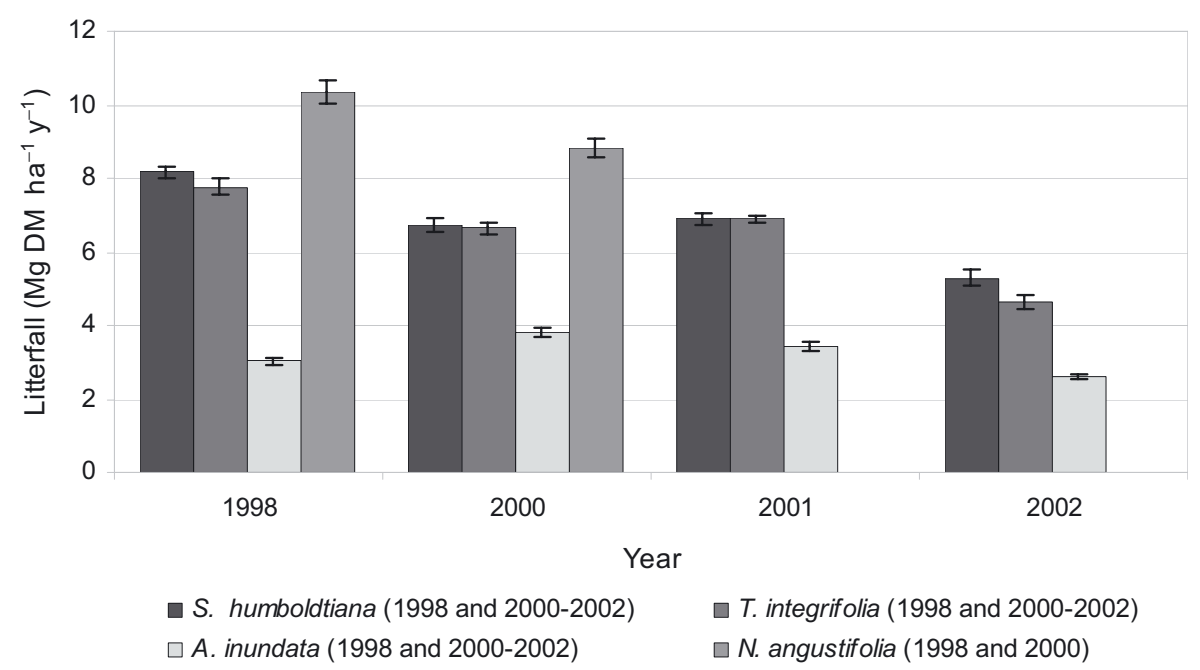

Figure 3. Forest annual litterfall production (mean $\mathrm{Mg} \mathrm{DM} \mathrm{ha} \mathrm{y}^{-1} \mathrm{y}^{-1}$ and its standard error) in forests of: T. integrifolia; S. humboldtiana; A. inundata; and N. angustifolia, located in the P.N.P.D. (period: 1998-2002).

In the remaining forest sites, the contribution of flowers and fruits was significantly higher in 1998 (T. integrifolia: $H=4.6$, $p>0.05 ;$ A. inundata: $H=0.54, p>0.05$. S. humboldtiana: $H=22.4 ; p<0.001^{* * *}$; and $N$. angustifolia: $H=8.1, p<$ $0.001 * * *)$.

The contribution of other species present in the forest declined significantly in mono-specific forests (T. integrifolia and S. humboldtiana) in 2002 (the least productive year). In mixed forests (A. inundata and $N$. angustifolia), this interannual decline was not observed; however, the production of other species in the A. inundata forest was significantly higher in the year 2000, and reached a value of $2.42 \mathrm{Mg} \mathrm{ha}^{-1} \mathrm{y}^{-1}$ (S. humboldtiana: $H=12.3, p=0.0064^{* *} ;$ T. integrifolia: $H=44.7, p<0.001^{* * * ;}$ and A. inundata: $H=18.8$, $\left.p<0.0005^{* * *}\right)$.

Generally, the contribution of leaf production exceeds the branch contribution, resulting in leave/branch (L/B) ratios higher than 1.0, being highest in the $N$. angustifolia forest (Tab. I). In the remaining forest types, in spite of the fact that branch contribution was not so high (lower than 20\%), the mean value of the L/B index was always lower than 4.0 (Tab. I, Fig. 2), with highest value of L/B in the S. humboldtiana forest. Nevertheless, the relationship L/B did not show a clear pattern across the study years, and varies between 2.5 and 6.0 (Tab. I).

\subsection{Monthly pattern of fraction contribution to litterfall}

Table I and Figure 4 show mean monthly litterfall production and confidence intervals for each year of the period studied. Figure 4 allows the discrimination of the monthly pattern of the contribution of each forest, as well as the contribution of each fraction of the dominant species and of other species.

\subsubsection{Forest patterns of litterfall production}

Litterfall contribution in the four forest stands occurs during spring-summer (mainly from November to February). However, no significant differences were found when productions were discriminated by season, except for the mono-specific forest of $S$. humboldtiana $(H=19.7, p<0.001 * * *)$.

Nevertheless, if the monthly contribution is considered, differences become also significant in T. integrifolia and A. inundata forests, with litterfall productions being higher during spring-summer months (recovering about $40 \%$ of the annual input from November to February,). In these forests (except in the perennial forest, i.e. N. angustifolia), a secondary input peak is usually recorded in autumn (May to June); in both forests more than $10 \%$ of the annual litterfall production was recorded in May, in contrast to the evergreen $N$. angustifolia, where no difference among months was observed (T. integrifolia: $H=51.0, p<0.001^{* * *} ;$ A. inundata: $H=42.3$, $p<0.001^{* * *}$; and $N$. angustifolia: $H=9.35 ; p>0.05$ ).

\subsubsection{Fraction pattern of contribution (Fig. 4)}

Leaf production is significantly higher in spring-summer months in mono-specific forests (T. integrifolia and S. humboldtiana), while in mixed forests ( $N$. angustifolia and A. inundata), a production peak was recorded in autumn, which allows the identification of a summer-autumn pattern, with approximately $50 \%$ of leaf production was recorded in that period (S. humboldtiana: $H=103, p<0.001^{* * *}$; T. integrifolia: $H=35.4, p<0.001^{* * *}$; A. inundata: $H=20.5$, $p<0.001^{* * *}$; and N. angustifolia: $\left.H=11.2, p<0.05^{*}\right)$.

The branch-fall pattern is less evident, but higher values were generally found in August. Significant differences were found in the $S$. humboldtiana forest for late winter and spring 

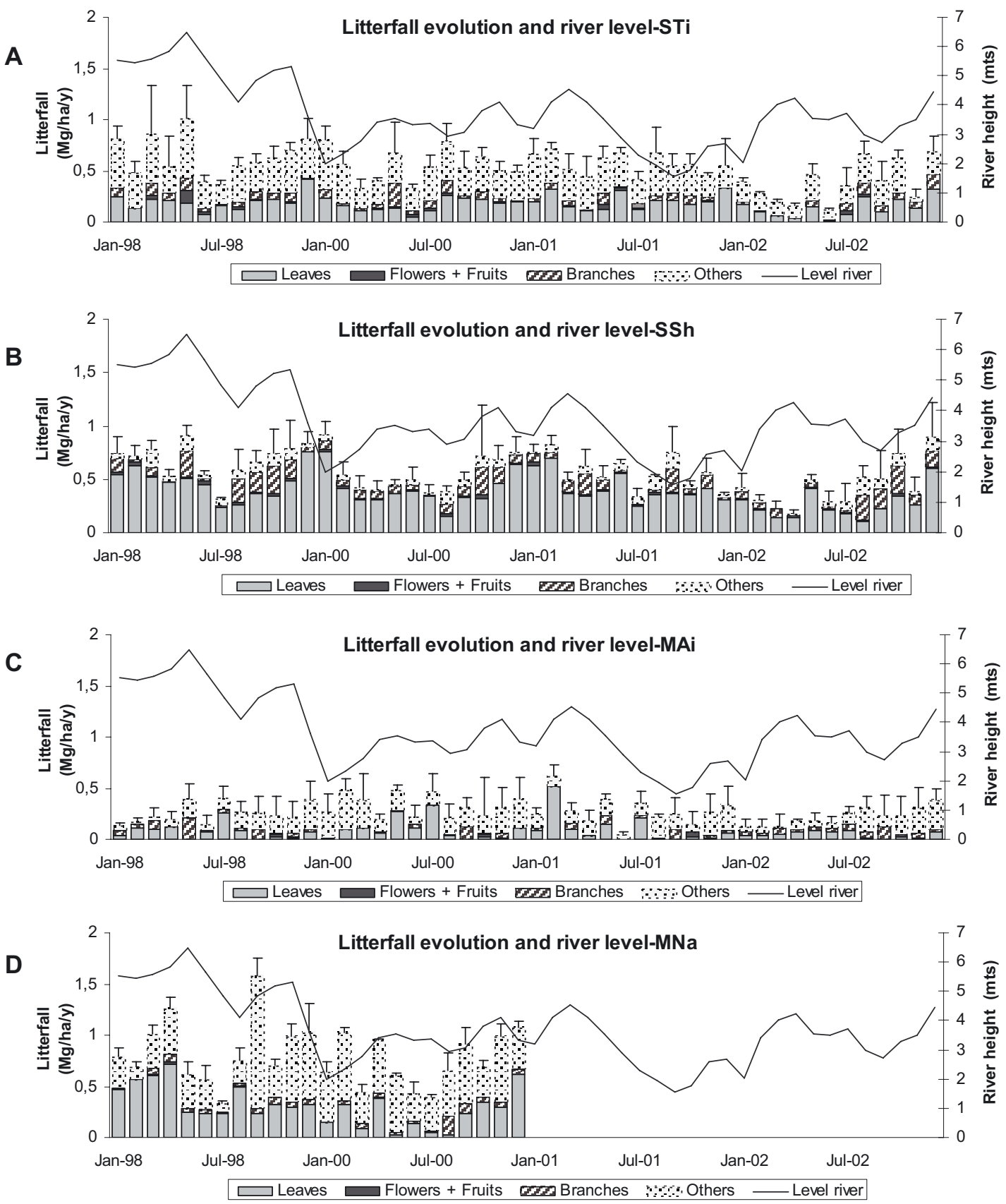

Figure 4. Monthly pattern of litterfall production (mean Mg DM ha ${ }^{-1} \mathrm{y}^{-1}$ and its standard error) in forests of: A: T. integrifolia; B: S. humboldtiana; C: A. inundata; and D: N. angustifolia, located in the P.N.P.D. (period: 1998-2002). The contribution of each fraction (leaf production, branches, and flowers+fruits) of dominant species and of the remaining species ("other") conforming the total forest production, is indicated. Height (in $\mathrm{m}$ ) of the river level is also given.

months. In the A. inundata forest, branch production is significantly lower in spring-summer months. No significant differences were found for T. integrifolia, in spite of $50 \%$ of branches fell from August to November; and regarding $N$. angustifolia, branches represent more that $10 \%$ of total litterfall collected in May and October (S. humboldtiana: $H=14.4$, $p<0.05^{*} ; A$. inundata: $H=7.93, p<0.05^{*} ;$ T. integrifolia: $H=3.21, p>0.05$; and $N$. angustifolia: $H=4.52, p>0.05$ ).
A seasonal pattern of flower and fruit production was identified for mixed forests; in A. inundata forest $70 \%$ of flowers and fruits fell in October (spring) and in N. angustifolia $60 \%$ fell between March and April (late summer-early autumn). Moreover, in A. inundata forest, reproductive structures collected in October accounting for more than 15\% of the total litterfall, in spite of their small size. Therefore, highly significant differences were found between this month and the remaining 
months (A. inundata: $H=20.2, p<0.001^{* * *}$; and $N$. angustifolia: $H=9.64, p<0.01 * *)$. In mono-specific forests, flowers and fruits fell during the whole year. However, in the T. integrifolia forest this contribution was significantly concentrated in autumn-winter months $(H=41.3 ; p<0.001 * * *)$, being April the month with the higher production (36\% of total annual flower fall). In $S$. humboldtiana forest, significant differences occurred only some years (2000 and 2001; $H=41.9$, $\left.p<0.001^{* * *}\right)$, recording significantly high values of the reproductive organs for spring-summer months. No significant differences were found among the remaining years $(H=4.09$, $p>0.05)$.

Concerning the monthly contribution of other forest species, in S. humboldtiana forest more than $70 \%$ of production was recorded from August to October, with significantly higher values; only for $T$. integrifolia these differences were not significant. With regard to both mixed forests $(A$. inundata and $N$. angustifolia) about $50 \%$ of the contributions from other species was recorded from September to December (spring). However, while the A. inundata forest showed significant differences, no significant difference was found for the $N$. angustifolia forest (A. inundata: $H=24.7, p<0.001^{* * * ;} N$. angustifolia: $H=2.95, p>0.05 ;$ S. humboldtiana: $H=30.5$, $p<0.001^{* * *}$; and T. integrifolia: $H=2.87, p>0.05$ ).

\subsection{Relationship between the surface water level and litterfall production}

Annual mean river level (Fig. 4) was significantly higher in 1998 and lower in 2002, since 2002 was a dry year $(H=96.42$, $\left.p<0.001^{* * *}\right)$. Also, river height level $\left(h_{\mathrm{wl}}\right)$ significantly increased during March, April, and May (autumn), compared to spring and summer months (September-January), indicating a clear autumn flood peak, with the river level decreasing the rest of the year, especially during January $(H=183$, $\left.p<0.001^{* * *}\right)$.

Correlations between total production (taking into account monthly average of forest production) and leaf production (taking into account monthly average of leaf production) of each forest with the $h_{\mathrm{wl}}$ (considering monthly average of $h_{\mathrm{wl}}$ ) were significant in relation to different years (1998 and 2002) and different months (March, April, and May).

When correlating monthly total forest production of each forest site and leaf production of the dominant species with $h_{\mathrm{wl}}$ in two autumn seasons (March, April and May of 1998 and 2002), it is observed that in both semi-deciduous and deciduous species (T. integrifolia, S. humboldtiana, and A. inundata), $h_{\mathrm{wl}}$ variations are correlated with forest litterfall (S. humboldtiana: $r=0.68, p<0.01^{* *} ;$ T. integrifolia: $r=0.53$, $p=0.01^{* *}$; and A. inundata: $\left.r=0.63, p<0.01^{* *}\right)$. For the deciduous species (A. inundata) leaf production is independent (Fig. 4) from oscillations of $h_{\mathrm{wl}}$ (S. humboldtiana: $r=0.54, p<0.01^{* *} ;$ T. integrifolia: $r=0.45, p<0.05^{*}$; and A. inundata: $r=-0.25, p>0.05)$.

For the evergreen forest ( $N$. angustifolia), litterfall do not show a distinctive pattern. There is no correlation between litterfall and $h_{\mathrm{wl}}$.

\section{DISCUSSION}

\subsection{Annual production of litterfall}

\subsubsection{Forest litterfall production}

Mono-specific and mixed studied forests are significantly different regarding litterfall production. In S. humboldtiana, T. integrifolia and $N$. angustifolia forests, total litterfall production was significantly higher than the estimation of $5.6 \mathrm{Mg} \mathrm{ha}^{-1} \mathrm{y}^{-1}$ for temperate-warm forests (Brinson et al., 1980), resembling values provided by Haase (1999) for sub-Tropical forests subjected to seasonal floods (6.9 $\left.\mathrm{Mg} \mathrm{ha}^{-1} \mathrm{y}^{-1}\right)$.

The value recorded in the $T$. integrifolia forest (6.5 $\mathrm{Mg} \mathrm{ha}{ }^{-1} \mathrm{a}^{-1}$ ) was also lower than that found by Neiff and Poi de Neiff (1990; 8.2 $\left.\mathrm{Mg} \mathrm{ha}^{-1} \mathrm{y}^{-1}\right)$ for the same species; the difference can be due to tree densities, since the tree density of this mono-specific forest of the P.N.P.D. is relatively low (820 trees ha ${ }^{-1}$, indicating forest maturity), while Neiff and Poi de Neiff (1990) estimated a very high density of 8000 trees $\mathrm{ha}^{-1}$, corresponding to a young $T$. integrifolia forest. The litterfall production of mixed A. inundata forest differs from the last cited value, since, as it is deciduous and, hence, has a shorter photosynthesis period.

Obviously, all the forests studied significantly exceed the value reported $\left(0.3 \mathrm{Mgha}^{-1} \mathrm{y}^{-1}\right)$ for meso-thermic subTropical forests of northern Argentina (Carnevale and Lewis, 2001), giving support to the hypothesis of higher productivity for floodplain forests (Brinson, 1990; Haase, 1999; Junk et al., 1989).

\subsubsection{Composition of litterfall production by fractions}

It is possible to differentiate the forests studied according to leaf production during the studied period, but it is not possible to identify them according to the production of branches, because they presented similar values. The reproductive structures were in general low $(<3 \%)$ in all forests, and it is possible to differentiate between mono-specific that mixed forest (these having higher values).

It should be noted the important contribution of "others" in the litterfall production, which exceeds sometimes $50 \%$ of the total. While this fact is expected in mixed forests, it is also found in the mono-specific forest of T. integrifolia, where $S$. humboldtiana leaves were transported by wind form nearby stands, and mixed with those from the former.

\subsection{Inter-annual variation in total litterfall production}

\subsubsection{Forest litterfall production}

There is a decrease of litterfall production in all the studied forest from 1998 to 2002 . This change can be associated at to the decrease of the river height observed in the same period. 


\subsubsection{Litterfall fractions}

Leaf production and "others" decreased during the period of study in the mono-specific forest, while branch production showed a decrease only for the A. inundata stand.

The reproductive structures are more abundant in the colonizer trees. This fraction associated with the decrease of production in S. humboldtiana and N. angustifolia forests.

\subsubsection{Relationship leaf production/branches}

Forest types studied herein can be also differentiated by the contribution of leaf production to the total litterfall production. In this way, the $\mathrm{L} / \mathrm{B}$ relationship is sometimes used as a maturity index (Martín et al., 1994). In general, the contribution of leaf production exceeds that of branches (Gallardo et al., 1989), but that situation is only here clearly recorded in $N$. angustifolia forest, which had the lowest tree density.

It should be taken into account that the branch-production peak, which occurs in August in the study area, is usually associated with an increase of wind speeds. Moreover, windy years (with higher branch production; e.g., 1998) are usually followed by periods of scarce production (Gallardo et al., 1989), as it may be observed for the A. inundata forest. This is, in any case, the least mature forest (in accordance with its high tree density).

Therefore, if leaf and branch productions are controlled by different external factors (soil water content and winds, respectively) it is consistent with the high inter-annual variation of the $\mathrm{L} / \mathrm{B}$ ratio, that does not show a clear pattern throughout the studied period. In any case, according to this ratio, there is a trend in forest maturity following the sequence:

$$
\begin{aligned}
\text { A. inundata } & <T \text {. integrifolia }<\text { S. humboldtiana } \\
& <N \text {. angustifolia. }
\end{aligned}
$$

\subsection{Monthly pattern of contribution}

The significantly higher and earlier leaf production during spring-summer (S. humboldtiana: $H=103, p<0.001^{* * *}$; and T. integrifolia: $H=35.4, p<0.001 * * *)$ in mono-specific forests (T. integrifolia and $S$. humboldtiana) indicates that litterfall production matches the period of highest photosynthetic value, while in mixed forests (A. inundata and $N$. angustifolia) the highest litterfall production occurs during autumn-winter (A. inundata: $H=20.5, p<0.001^{* * *}$; and $N$. angustifolia: $\left.H=11.2, p<0.05^{*}\right)$, a pattern commonly found in deciduous forests (such as A. inundata).

The mono-specific $S$. humboldtiana is the only forest where production of the dominant species reflects the curve of total production of the site (Fig. 2). The N. angustifolia forest, despite being the more mature forests, shows a production pattern conditioned by the litter of $S$. humboldtiana, evidencing a significant difference $(H=30.5, p<0.001 * * *)$ between total production of the site and of the dominant species. In mixed forests leaf production of the dominant species does not reflect the total production pattern of the site, also indicating a weak influence of the dominant species on that pattern.

\subsection{Relationship litterfall production-river height}

The hydrological level varied in the study period, decreasing from 1998 (flood peak) to 2002 (dry year). During these years, phases of annual flood (occurring from March to May) were identified. Taking this into account, correlations between total and leaf productions of each forest with $h_{\mathrm{wl}}$ were significant considering different years (1998 and 2002) and months (March, April, and May). For these periods, a significant positive relationship was found between $h_{\mathrm{wl}}$ and litterfall production in semi-deciduous forests (S. humboldtiana, $T$. integrifolia, and A. inundata). This means that litterfall productions of these forests are associated to river conditions and the changes on the river dynamic may, consequently, alter biogeochemical characteristics and nutrient flows in the sites.

Litterfall production in the perennial forest ( $N$. angustifolia) was independent from fluctuations of $h_{\mathrm{wl}}$, which is consistent with this species, being more dependent on water stress (dry years).

On the other hand, leaf production was also positively related with $h_{\mathrm{wl}}$ in mono-specific semi-deciduous forests ( $T$. integrifolia and $S$. humboldtiana), while no relationship was found in the deciduous forest (A. inundata).

These results allow us to make some assumptions on the composition and periods of plant material that returns to the soil. It was observed, in general, that in mono-specific forests (T. integrifolia and $S$. humboldtiana, more closely related to the hydrological dynamics), litterfall production peaks occur after the flooding phase that is at the beginning of the period when the river level begins to decrease. In the case of the mono-specific $S$. humboldtiana forest, there is an evident late spring pattern and the litterfall production coincides with the end of the flooding phase (Neiff and Poi de Neiff, 1990; Zamboni and Aceñolaza, 2004). In these forests a phenological reaction of trees seem to occur in response to the flood pulse, which may have deep effects in the dynamics of biogeochemical cycles and, hence, in nutrient release toward the soil (Gallardo et al., 1998).

\section{CONCLUSIONS}

(1) Litterfall productions of evergreen and semi-deciduous forests of the National park of the Pre-Delta of the Paraná River (Argentina) have similar values to those of sub-Tropical seasonally flooding forests.

(2) The decrease of annual production of litterfall during the study period (1998-2002) can be associated with the response of vegetation to the exceptional high flood recorded in 1998, and with the dry period that occurred during 2002. Therefore, it is evident that the height of the river level, conditions the productions of the two semi-deciduous forests (Salix humboldtiana and Tessaria integrifolia).

(3) The deciduous forest of Albizia inundata is the less productive forest and its litterfall production is not directly correlated with the flood pulses.

(4) Litterfall production in the evergreen Nectandra angustifolia forest was also independent from height fluctuations of 
the river level, and had the highest leaf/branch ratio and the lowest tree density, indicating a higher maturity state.

(5) The production of reproductive organs has practically no contribution to the total litter-fall; but the higher amounts of this fraction were logically found in the two colonizer trees (A. inundata and T. integrifolia).

(6) Only the mono-specific $S$. humboldtiana forest displays a net and repeated pattern of late spring production (after the flooding phase, associated with the beginning of the water deficit period), having a high percentage of leaf production and a scarce contribution from other species.

Acknowledgements: We are grateful to R. D'Angelo, R. Zanello, and O. Bejarano for their help in field data collection; and to "National Parks Administration (APN)" for allowing this study. Recognitions to the anonymous reviewers which helped to improve the original manuscript. This research has been partially funded by the PICT-ANPCyT 11928, the PIP-CONICET 6374, and the PID-UNER 2089/01.

\section{REFERENCES}

Aceñolaza P., Sione W., Kalesnik F., and Serafíni M.C., 2005. Determinación de unidades homogéneas de vegetación en el Parque Nacional Pre-Delta (Argentina). Serie Misc. INSUGEO 14: 81-90.

Aceñolaza P.G., Zamboni L.P., and Gallardo J.F., 2006. Ciclos biogeoquímicos de bosques de la llanura de inundación del río Paraná (Argentina): Aporte de hojarasca. In: Gallardo Lancho J.F. (Ed.), Medioambiente en Iberoamérica: Visión desde la física y la química en los albores del SXXI, Sociedad Iberoamericana de Física y Química Ambiental, Badajoz, España, vol. 2, pp. 529-536.

Aceñolaza P., Zamboni L.P., Sione W., and Kalesnik F., 2008. Caracterización de la región superior del Complejo litoral del Río Paraná: Grandes Unidades de ambiente. Serie Misc. INSUGEO 17: 293-309.

Bray J. and Gorham E., 1964. Litter production in forest of the world. Adv. Ecol. Res. 2: 101-157.

Brinson M.M., 1990. Riverine forests. In: Lugo A.E., Brinson M.M., and Brown S. (Eds.), Forest wetlands, Elsevier, Amsterdam, pp. 87-141.

Brinson M.M., Bradshaw H.D., Holmes R.N., and Elkins J., 1980. Litterfall, stemflow and throughfall nutrient fluxes in an alluvial swamp forest. Ecology. 61: 827-835.

Carnevale N. and Lewis, J.P., 2001. Litterfall and organic matter decomposition in a seasonal forest of the eastern Chaco (Argentina). Rev. Biol. Trop. 49: 203-212.

Casco S., Neiff M., and Neiff J.J., 2005. Biodiversidad en ríos del litoral fluvial. Utilidad del software PULSO. Serie Misc. INSUGEO 14: $105-119$

Clarke P.J. and Allaway W.G., 1996. Litterfall in Casuarina glauca Coastal Wetland Forest. Aust. J. Bot. 44: 373-380.

Eglin T., Walter C., Nys C., Follain S., Forgeard F., Legout A., and Squividant H., 2008. Influence of waterlogging on carbon stock variability at hillslope scale in a beech forest (Fougères forest, West France). Ann. For. Sci. 65: 202.

Gallardo J.F., Martín A., and Santa Regina I., 1998. Nutrient cycling in deciduous forest ecosystems of the "Sierra de Gata" mountains: Nutrient supplies to the soil through both litter and throughfall. Ann. For. Sci. 55: 771-784.
Gallardo J.F., Santa Regina I., and San Miguel C., 1989. Ciclos biogeoquímicos en bosques de la Sierra de Béjar (Salamanca, España). 1. Producción de hojarasca. Rev. Ecol. Biol. Sol. 26: 35-46.

Gauch H.G., 1982. Sampling methods. In: Multivariable analysis in community ecology, Cambridge Univ. Press, Cambridge, pp. 43-63.

Godoy J.R., Petts G., and Salo J., 1999. Riparian flooded forest of the Orinoco and Amazon basins: a comparative review. Biodivers. Conserv. 8: 551-586.

Grigg A.H. and Mulligan D.R., 1999. Short note: Litterfall from two $e u$ calypt woodlands in central Queensland. Aust. J. Ecol. 24: 662-664.

Haase R., 1999. Litterfall and nutrient return in seasonally flooded and non-flooded forest of the Pantanal, Mato Grosso, Brazil. For. Ecol. Manage. 117: 129-147.

InfoStat., 2002. InfoStat versión 1.1. Grupo InfoStat, F.C.A., Universidad Nacional de Córdoba, Argentina.

Jozami J.M. and Muñoz J.D.D., 1984. Árboles y arbustos indígenas de la provincia de Entre Ríos. I.P.N.A.P.S., CONICET-U.N.L., Santa Fé, Argentina, $85 \mathrm{p}$.

Junk W., Bayley P., and Sparks R., 1989. The flood pulse concept in riverfloodplain systems. Can. Spec. Publ. Fish. Aquat. Sci. 106: 110-127.

Marchetti Z. and Aceñolaza P.G., 2005. Detección satelital y descripción de patrones de vegetación en islas del Paraná Medio. Serie Misc. INSUGEO 14: 191-197.

Martín A., Santa Regina I., and Gallardo J.F., 1994. Ciclos biogeoquímicos en un bosque perenne de encina (Quercus rotundifolia) en las proximidades de Salamanca (España): Retorno potencial. In: Gallardo J.F. (Ed.), Biogeoquímica de ecosistemas, Junta de Castilla y León, Valladolid, España, pp. 151-160.

Monedero C. and González V., 1995. Producción de hojarasca y descomposición en una selva nublada del ramal interior de la cordillera de la costa, Venezuela. Ecotrópicos. 8: 1-14.

Neiff J.J. and Poi de Neiff A., 1990. Litterfall, leaf decomposition and litter colonization of T. integrifolia (Compositae) in the Paraná River floodplain. Hydrobiology. 203: 45-52.

Proctor J., 1983. Tropical forest litterfall. I. Problems of data comparison. In: Sutton S.L., Whitmore T.C., and Chadwick A.C. (Eds.), Tropical rain forest: ecology and management, Blackwell Sci., Oxford, pp. 267-273.

Proctor J., 1984. Tropical forest litterfall. II. The data set. In: Chadwick A.C. and Sutton S. (Eds.), Tropical Rain-Forest: The leeds symposium, Proc. Leeds Philosophical \& Literary Soc., Leeds, Gran Bretaña. pp. 83-113.

Raimundo F., Martins A., and Madeira M., 2008. Decomposition of chestnut litterfall and eight-year soil chemical changes under a notillage management system in Northern Portugal. Ann. For. Sci. 65: 408.

Rojas A.E. and Saluso J.H., 1987. Informe Climático de la Provincia de Entre Ríos. Publ. Técnica $N^{\circ}$ 14. E. E. A. Paraná, Entre Ríos, Argentina, $20 \mathrm{p}$.

Santa Regina I., Gallardo J.F., Rico M., Martín A., Gallego H.A., Moreno G., and Cuadrado S., 1991. Datos preliminares sobre biomasa aérea, producción y características edafoclimáticas de ecosistemas forestales de Quercus pyrenaica (Sierra de Gata, Salamanca). Stud. Oecol. 8: 147-158.

Williams-Linera G. and Tolomé J., 1996. Litterfall, temperate and tropical dominant trees, and climate in a Mexican lower-montane forest. Biotropica 28: 649-656.

Zamboni P. and Aceñolaza P., 2004. Aporte al conocimiento de ciclos de materia orgánica en formaciones boscosas de la llanura de inundación del río Paraná. Serie Misc. INSUGEO 12: 5-12. 